\title{
Iron Therapy in Inflammatory Bowel Disease
}

\author{
Aditi Kumar ${ }^{1, *(1)}$ and Matthew J. Brookes ${ }^{1,2}(\mathbb{D}$ \\ 1 The Royal Wolverhampton NHS Trust, Wolverhampton WV10 0QP, UK; matthew.brookes@nhs.net \\ 2 Research Institute in Healthcare Science (RIHS), University of Wolverhampton, Wolverhampton WV1 1LY, UK \\ * Correspondence: aditikumar@nhs.net
}

Received: 1 November 2020; Accepted: 10 November 2020; Published: 12 November 2020

\begin{abstract}
The most common complication seen in inflammatory bowel disease (IBD) patients is iron deficiency anaemia (IDA). Symptoms such as chronic fatigue can be as debilitating to IBD patients as pathological symptoms of abdominal pain and diarrhoea. Recognising and correcting anaemia may be as important as managing IBD symptoms and improving overall quality of life. Thus, iron replacement should be commenced the moment IDA is identified. Although intravenous iron is now considered standard treatment for IBD patients in Europe, oral iron still appears to be the preferred option. Advantages of oral iron include greater availability, lower costs and ease of applicability. However, its multitude of side effects, impact on the microbiome and further exacerbating IBD activity can have consequences on patient compliance. The newer oral iron formulations show promising safety and efficacy data with a good side effect profile. Intravenous iron formulations bypass the gastrointestinal tract absorption thereby leading to less side effects. Multiple studies have shown its superiority compared to oral formulations although its risk for hypersensitivity reactions continue to lead to clinician hesitancy in prescribing this formulation. This article provides an updated review on diagnosis and management of IDA in IBD patients, discussing the newer oral and intravenous formulations.
\end{abstract}

Keywords: iron; inflammatory bowel disease; iron therapy; intravenous iron; oral iron; iron deficiency

\section{Introduction}

Inflammatory bowel disease (IBD) is recognized as a group of chronic relapsing-remitting diseases that affect the small and large bowel [1]. Its incidence and prevalence are rising globally, with higher rates reported in the western nations [1,2]. There are multiple extraintestinal manifestations associated with IBD with the most common complication presenting as anaemia [1]. Anaemia in IBD is detected in up to $70 \%$ of inpatients and $20 \%$ of outpatients [3] and is thought to affect one third of the IBD population at any one time [4]. Anaemia in IBD patients can be found both at the initial diagnosis stage and during repeated flares [5], more commonly seen in Crohn's disease than Ulcerative Colitis [1], with females at higher risk than males [6]. Importantly, there is a greater risk of hospitalization and surgery rates in IBD with concomitant anaemia [7]. It is also demonstrated to be the most frequent comorbid condition associated with death, although this may just reflect the severity of the underlying IBD condition [8]. The most common causes for anaemia in IBD include iron deficiency, vitamin B12 deficiency and anaemia of chronic disease (ACD) (see Table 1). This review article will focus specifically on the management of iron deficiency anaemia (IDA).

\subsection{Iron Absorption, Iron Deficiency and Iron Deficiency Anaemia}

Iron is a vital element involved in several cellular functions, including but not limited to DNA repair, gas exchange, mitochondrial function and free radical production [9]. Dietary iron is found in two forms: haem, which arises from haemoglobin and myoglobin in the forms of meat, poultry and 
fish, and non-haem, which mainly comes from plants [10]. Haem iron is more efficiently absorbed than non-haem iron [11].

Table 1. Diagnosing and managing anaemia in inflammatory bowel disease (IBD).

\begin{tabular}{|c|c|c|c|c|}
\hline $\begin{array}{c}\text { Type of } \\
\text { Anaemia }\end{array}$ & Definition of Anaemia & Diagnosis & $\begin{array}{l}\text { Microscopic } \\
\text { Findings }\end{array}$ & Management \\
\hline IDA & \multirow{4}{*}{$\begin{array}{c}\text { Women: } \mathrm{Hb}<120 \mathrm{~g} / \mathrm{L} \\
\text { Men: } \mathrm{Hb}<130 \mathrm{~g} / \mathrm{L} \\
\text { Pregnancy: } \mathrm{Hb}<110 \mathrm{~g} / \mathrm{L}\end{array}$} & $\begin{array}{c}\text { Low serum iron } \\
\text { Low ferritin }(<30 \mathrm{ug} / \mathrm{L}) \\
\text { Serum ferritin }<100 \mathrm{ug} / \mathrm{L} \text { in } \\
\text { inflammatory disease } \\
\text { Low transferrin saturation } \\
(\text { TSAT }<20 \%) \\
\text { Transferrin levels increased } \\
\text { Reduced } \mathrm{MCH}\end{array}$ & $\begin{array}{l}\text { Microcytic and } \\
\text { hypochromic } \\
\text { erythrocytes }\end{array}$ & $\begin{array}{c}\text { Oral or IV } \\
\text { replacement } \\
\text { Blood transfusion }\end{array}$ \\
\hline $\begin{array}{c}\text { Vitamin B12 } \\
\text { deficiency }\end{array}$ & & $\begin{array}{c}\text { Low B12 levels } \\
\text { Elevated methylmalonic acid } \\
\text { Elevated total homocysteine } \\
\text { Elevated } \mathrm{MCH}\end{array}$ & $\begin{array}{l}\text { Megaloblastic } \\
\text { anaemia }\end{array}$ & $\begin{array}{l}\text { High dose IV or } \\
\text { oral B12 } \\
\text { replacement }\end{array}$ \\
\hline $\mathrm{ACD}$ & & $\begin{array}{c}\text { Low reticulocyte count } \\
\text { Low iron } \\
\text { Low TSAT }(<20 \%) \\
\text { Transferrin levels normal } \\
\text { or decreased } \\
\text { Normal or raised Ferritin }(<100) \\
\text { Low or normal MCH }\end{array}$ & $\begin{array}{l}\text { Normochromic and } \\
\text { normocytic } \\
\text { erythrocytes }\end{array}$ & $\begin{array}{l}\text { Treatment of } \\
\text { underlying } \\
\text { condition } \\
\text { Blood transfusions } \\
\text { Erythropoiesis } \\
\text { stimulating agents }\end{array}$ \\
\hline IDA and ACD & & $\begin{array}{c}\text { Normal or raised } \\
\text { transferrin saturation } \\
\text { Normal or reduced } \mathrm{MCH}\end{array}$ & $\begin{array}{l}\text { Hypochromic } \\
\text { erythrocytes }\end{array}$ & \\
\hline
\end{tabular}

IDA: iron deficiency anaemia, ACD: anaemia of chronic disease, MCH: mean corpuscular haemoglobin, $\mathrm{Hb}$ : haemoglobin.

Iron absorption occurs predominantly in the duodenum and upper jejunum (Figure 1).

Absorption is facilitated by ascorbic acid, citrate and gastric acid and inhibited by dietary sources such as phytates, tannins and antacids, all commonly found in plants [12]. There are two absorption pathways, depending on its iron formulation. Non-haem iron is present in its ferric form $\left(\mathrm{Fe}^{3+}\right)$ and must first be reduced to ferrous iron $\left(\mathrm{Fe}^{2+}\right)$ by the enzyme duodenal cytochrome B (DcytB), which is present on the apical membranes of enterocytes [13]. $\mathrm{Fe}^{2+}$ can then be absorbed across the apical surface of duodenal enterocytes via the divalent metal transporter 1 (DMT1) [11]. Once inside the enterocyte, $\mathrm{Fe}^{2+}$ is stored as ferritin or exported across the basolateral surface to plasma through ferroportin [14]. However, before iron can be transported outside the enterocyte, $\mathrm{Fe}^{2+}$ must be oxidised back to $\mathrm{Fe}^{3+}$ via hephaestin or ceruloplasmin. Haem iron, on the other hand, can be absorbed directly into the enterocyte via the haem carrier protein (HCP1) and then released into plasma via the haem exporter FLVCR1. Once inside the enterocyte, Haem can also undergo degradation, releasing $\mathrm{Fe}^{2+}$ through the enzymatic reaction of haem oxygenase $(\mathrm{HO}) . \mathrm{Fe}^{2+}$ is then released into the plasma through ferroportin [13]. Ferroportin is the sole iron exporter and is controlled by hepcidin, a liver-derived peptide hormone $[12,14]$. Hepcidin binds to ferroportin and controls ferroportin concentration through promoting its endocytosis [14]. The presence of inflammation can increase hepcidin levels and impair the exportation of cellular iron into plasma by causing ferroportin degradation [15].

The human body can store approximately 3-4 g of iron with a resultant daily iron loss of 1-2 mg, which requires a small amount to be replenished from the individual's diet $[10,16,17]$. Daily iron can be lost through skin desquamation and through the intestine [15], urinary tract and bile ducts [16,17]. The two main sources of excessive iron loss are either through menstrual bleeding or intestinal bleeding $[10,16]$. In IBD, chronic intestinal bleeding exceeds dietary iron absorption resulting in a negative iron balance, ultimately leading to iron deficiency anaemia [18]. 


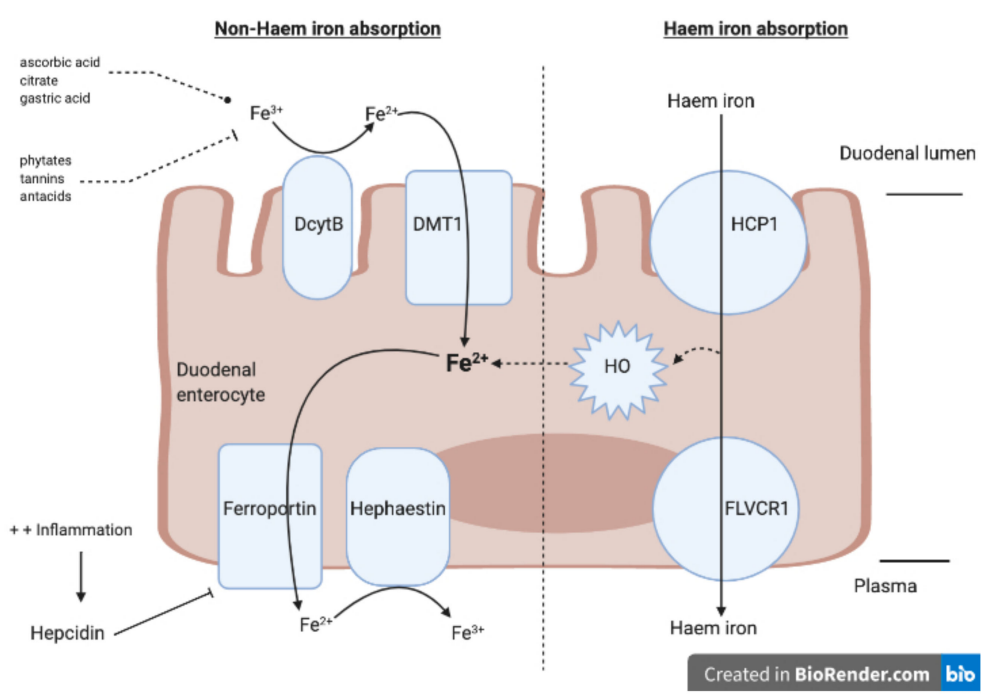

Figure 1. Absorption of haem and non-haem iron through the duodenal enterocyte. Non-haem absorption pathway: Ferric iron $\left(\mathrm{Fe}^{3+}\right)$ is first reduced to ferrous iron $\left(\mathrm{Fe}^{2+}\right)$ by the enzyme, Duodenal cytochrome B (DcytB). $\mathrm{Fe}^{2+}$ can then be absorbed across the apical surface via the divalent metal transporter 1 (DMT1) and exported via ferroportin. Haem absorption pathway: Haem iron is absorbed directly into the enterocyte through haem carrier protein (HCP1). Once inside the enterocyte, haem iron can either be released into plasma via the FLVCR1 receptor or be converted to $\mathrm{Fe}^{2+}$ through the enzyme haem oxidase (HO). Before exportation, $\mathrm{Fe}^{2+}$ is oxidized back to its $\mathrm{Fe}^{3+}$ form via Hephaestin. Hepcidin controls ferroportin and will inhibit iron export in the presence of inflammation. Facilitators of iron absorption include ascorbic acid, citrate and amino acids while inhibitors include phytate, tannins and antacids.

The World Health Organisation (WHO) has recognised IDA as the most common disorder of the world with $30 \%$ of the population affected by this condition. WHO classifies anaemia as a haemoglobin $(\mathrm{Hb})$ level less than $120 \mathrm{~g} / \mathrm{L}$ for women and less than $130 \mathrm{~g} / \mathrm{L}$ for men. In pregnancy and IDA, $\mathrm{Hb}$ should be less than $110 \mathrm{~g} / \mathrm{L}$ [19]. Generally, low serum iron and ferritin levels are used to diagnose IDA [17]. However, ferritin is an acute phase protein and is increased in the presence of chronic inflammation [4]. The European Crohn's and Colitis Organisation (ECCO) guidelines state ferritin levels should be less than $30 \mathrm{ug} / \mathrm{mL}$ with IBD patients in remission (in the absence of inflammation) or mild disease and less than $100 \mathrm{ug} / \mathrm{mL}$ in active disease [20]. Transferrin levels can also be increased in IDA, although it is a negative acute phase protein and is decreased in chronic inflammation. Transferrin saturations are generally low in IDA $(<20 \%)$ and can be useful for diagnosis in unclear cases as it does not correlate with concomitant inflammation [17]. ACD and IDA can be difficult to distinguish and at times can be seen in combination with active IBD [17], where ferritin levels are between 30 and $100 \mathrm{ug} / \mathrm{L}$, and transferrin saturations are less than $20 \%$ [20].

Iron deficiency cannot be excluded in the presence of a normal $\mathrm{Hb}$ as patients must lose a significant amount of body iron before the $\mathrm{Hb}$ levels fall [21]. Thus, a low mean corpuscular haemoglobin (MCH) with a normal $\mathrm{Hb}$, or an increase in red cell distribution width (RDW) signifies mild iron deficiency without anaemia [21,22].

The aetiology of IDA in IBD patients is multifactorial. As stated above, IDA may be secondary to a reduced dietary intake or from chronic blood loss from inflamed mucosa [4]. Reduced iron absorption is another cause [1]. The majority of iron absorption occurs in the duodenum with a smaller proportion in the proximal ileum [23]. Consequently, iron absorption is impaired where there is duodenal inflammation. This is a result of elevated circulating hepcidin levels which inhibit enterocytes from releasing iron into circulation [1]. Reduced absorption can be seen in patients with extensive bowel resection with the residual complication of short bowel syndrome [4]. IDA can also be aggravated by medication used for IBD such as methotrexate, thiopurines, sulfasalazine and 
proton pump inhibitors $[15,17,24]$. Intestinal inflammation and extensive bowel resection can further perpetuate IDA by causing other vitamin deficiencies such as B12, folate and vitamin D [24,25].

\subsection{Clinical Manifestations of IDA and Its Effect on Quality of Life}

IDA can lead to a multitude of symptoms and can affect multiple organs. Common symptoms include fatigue, dizziness, headaches and shortness of breath particularly on exertion [26,27]. Signs to note include pallor of the nails, conjunctiva and skin [26]. Iron deficiency with or without anaemia can also lead to reduced exercise tolerability, skin dryness, hair breakage and restless leg syndrome [26,27]. There is also an increased risk of infection and alterations of thyroid hormones, catecholamines and neurotransmitters [17]. This can present with increased stress and depression in post-partum anaemia and poor cognitive and motor development outcomes in children. Among the elderly, this can be associated with increased hospitalisations and disability, greater risk for falls, impairment of executive function and dementia, all of which can lead to greater risk of death [28].

Chronic fatigue can affect virtually every aspect of daily life, resulting in significant biopsychosocial consequences [10]. It has been reported that chronic fatigue secondary to anaemia can debilitate IBD patients as much as organic symptoms of abdominal pain and diarrhoea [29]. In fact, it is thought that correcting patients' anaemia may be as important as controlling their IBD symptoms in relation to the favourable effect on quality of life (QoL) [17]. Multiple studies have shown that treating iron deficiency successfully can improve QoL unrelated to IBD disease activity [29]. This improvement was credited to increased feelings of well-being and mood, improved physical abilities and a rise in social activities with a strong correlation in haemoglobin levels in IBD patients [10].

\section{Management}

It is recommended to treat all patients with IDA with or without symptoms by correcting the underlying cause and by replenishing adequate iron stores [14]. Treatment should be initiated as soon as the patient is found to have IDA [30]. The goal of treatment is to obtain complete normalisation of anaemia and iron stores [1]. Although iron replenishment given either through the oral or intravenous (IV) route is the mainstay treatment, other options include erythropoietin-stimulating agents and blood transfusions.

\subsection{Oral Iron}

They are the most commonly prescribed iron replacement therapy due to low cost, availability and ease of administration [31]. Unless patients are intolerant, oral iron is preferred with mild IDA $(\mathrm{Hb}>100 \mathrm{~g} / \mathrm{L})$ in quiescent IBD [20]. For oral iron replacement to be effective, six months of treatment is recommended to replenish iron stores [14] and the $\mathrm{Hb}$ should increase by a minimum of $20 \mathrm{~g} / \mathrm{L}$ within 4 weeks of treatment [1].

Types of Preparations

Due to its greater bioavailability and solubility, the ferrous form of iron $\left(\mathrm{Fe}^{2+}\right)$ is generally found in the oral iron formulations $[18,24]$. Ferrous sulfate, ferrous gluconate and ferrous fumarate are the traditional formulations. For adequate absorption by enterocytes, $\mathrm{Fe}^{3+}$ must be reduced to $\mathrm{Fe}^{2+}$, catalysed by DcytB and enhanced by ascorbic acid [32]. The optimal oral iron dose is yet to be established with a recommended dose of 50-200 mg once daily [24]. ECCO recommends that the dose should not be higher than $100 \mathrm{mg}$ of elemental iron/day, as only $10-20 \mathrm{mg} /$ day of iron is effectively absorbed [24]. As side effects are dose-related [16,20], higher doses are not recommended particularly as there is no increase in iron absorption and efficacy [12]. Studies in iron-deficient women have further demonstrated that alternate-day single doses are more effective as iron absorption is reduced in more frequent daily dosing [33]. Moretti et al. established that oral iron doses of $60 \mathrm{mg}$ or greater will result in higher fractional absorption when dosages are spaced by $48 \mathrm{~h}$ due to the transient increase in 
hepcidin for up to $24 \mathrm{~h}$ [34]. To improve absorption further, iron tablets should be taken on an empty stomach or in a mildly acidic medium such as $250 \mathrm{mg}$ ascorbic acid or with a glass of orange juice [16].

\subsection{Ferric Maltol (Ferracru)}

Ferric maltol is a new oral iron formulation. It is formed from a stable complex of ferric $\left(\mathrm{Fe}^{3+}\right)$ iron with maltol. $\mathrm{Fe}^{3+}$ iron has been demonstrated to be less toxic to the gastrointestinal (GI) tract mucosa. Although, its use is not approved in the United States, it has been offered as treatment for IDA in the European Union since 2016 [35]. Once ferric maltol has been ingested, ferric iron enters the intestinal mucosa in its complex form, thereby minimising the formation of free iron. This allows for more efficacious uptake of ferric iron into the enterocytes [35,36]. Furthermore, a lower daily dose of ferric maltol is required to achieve adequate iron uptake. Studies have thus far been encouraging, demonstrating rapid improvements in $\mathrm{Hb}$ with a favourable safety and tolerability profile [36]. The efficacy and tolerability of ferric maltol in patients with IBD and IDA was evaluated in a randomised double-blind placebo-controlled trial. This study showed that patients in the ferric maltol group achieved $\mathrm{Hb}$ normalisation within 12 weeks of treatment as opposed to $13 \%$ in the placebo arm. Constipation, abdominal pain and flatulence were the most common side effects. However, this study was not a direct comparison to other iron formulations, patients were only included if their disease was in remission or non-severe and if they had previously failed treatment with other oral ferrous formulations $[35,36]$. Further studies have confirmed an acceptable safety profile for ferric maltol, demonstrating good tolerability and the majority of patients had $\mathrm{Hb}$ normalisation within 3 months [3]. Howaldt et al. also demonstrated greater improvements in short form (SF-36) and mental component summary (MCS) scores with ferric maltol over IV iron, suggesting a greater improvement in quality of life [37]. Despite this, ferric maltol is not recommended for patients with active IBD due to the potential risk of increased inflammation in the GI tract [38].

\subsection{Sucrosomial Iron}

This is a newer generation of oral iron that has been associated with high intestinal absorption and bioavailability. It is a preparation of ferric pyrophosphate transported within a phospholipid and sucrose esters of fatty acid membrane. Due to its lack of direct contact with the intestinal mucosa, there has been a low report of side effects [39]. It also requires a lower drug dose than the ferrous variants [40]. Adverse events reported with this drug include GI upset nausea and vomiting, a change in bowel habits, tenesmus, abdominal pain and intestinal bleeding. However, all events were reported as mild and none were directly associated with the medication itself [40]. There are limited studies with this drug in IBD patients, however, initial clinical data suggest that this may be a viable alternative [31].

\subsection{Advantages and Disadvantages of Oral Iron}

The advantages of oral iron include a well-established safety profile, its ease of route of administration and reduced cost [3]. In addition, oral iron is not associated with reduced productivity [41]. However, due to a high proportion (90\%) of non-absorbed iron remaining in the gut, there are a considerable amount of side effects with oral iron replacement, which can lead to discontinuation of treatment in $20 \%$ of patients [23,30,31]. Nausea, vomiting, altered bowel habits and abdominal pain are the most commonly experienced side effects. Nausea and abdominal discomfort are dose related and can occur 1-2 $\mathrm{h}$ after ingestion [42]. In this instance, the patient can trial delayed release enteric coated iron tablets. However, these tablets have reduced efficacy as they dissolve slowly in the duodenum where the majority of iron is absorbed [10,24]. In an attempt to improve tolerance and compliance, efforts are being made to develop newer iron formulations that have a reduced side effect profile. Data thus far suggest that newer iron formulations may be superior to traditional ferrous iron. However, in the absence of any head-to-head trials, it is not yet possible to draw any definitive conclusions [3]. 
Whether therapeutic oral iron is effective with active IBD remains uncertain, perhaps due to a lack of definitive efficacy data. However, there is established evidence that the presence of iron in the gut increases IBD activity by inducing oxidative stress at the site of bowel inflammation. Ferrous compounds are oxidated within the gut lumen or mucosa, which results in the release of activated hydroxyl radicals and the generation of reactive oxygen species [4]. These molecules can subsequently damage the intestine, causing a range of gastrointestinal symptoms [4,43]. Additionally, the presence of mucosal inflammation can further exacerbate ongoing iron malabsorption. Enteric coated ferrous formulations avoid this oxidation process by minimising iron release in the stomach but by doing so, also prevent iron absorption [10].

Oral iron also has a significant impact on microbial composition, which plays a central role in the pathogenesis of IBD. Oral iron can disrupt the gut bacterial diversity leading to change in disease activity with some bacteria more dependent on iron than others [44].

\section{IV Iron}

The updated guidelines from ECCO advise that first line treatment should be IV iron in patients with active IBD, severe anaemia $(\mathrm{Hb}<100 \mathrm{~g} / \mathrm{L})$, if previously intolerant to oral iron and for patients in need of concomitant treatment with erythropoietin (Epo) [20]. The cumulative dose for iron repletion is based on the patient's $\mathrm{Hb}$ and body weight, which can be calculated using the Ganzoni formula (total iron dose $=($ actual body weight $\times(15-$ actual $\mathrm{Hb}) \times 2.4+$ iron stores $)$ [45]. However, this is not consistently used in clinical practice as it is error-prone, inconvenient and underestimates iron requirements [46]. Additionally, specific product labels state specific dosing regimens which is oft preferred [45]. A simplified fixed-dose regimen for ferric carboxymaltose has been found to be more superior than the Ganzoni formula and is based on $\mathrm{Hb}$ and body weight. This formula can be applied in other iron formulations, which are also given at doses of $1000 \mathrm{mg}$ [46].

\subsection{Parenteral Iron Preparations}

The selection of the IV agent is dependent on multiple factors including patient preference, costs and local availability [17]. It is important to note that each IV formulation follows a different protocol and, as of yet, one cannot compare the efficiency and safety profiles between the various formulations due to the lack of any large competitive trials. See Table 2 for a breakdown of the characteristics of the different IV preparations.

Table 2. Characteristics of different intravenous iron preparations.

\begin{tabular}{|c|c|c|c|c|}
\hline & Molecular Weight & Half-Life & Administration & Disadvantages/Risks \\
\hline $\begin{array}{l}\text { HMW Dextran } \\
\text { (DexFerrum) }\end{array}$ & $100-500 \mathrm{kDa}$ & 3-4 days & Single dose & Anaphylactoid reaction \\
\hline $\begin{array}{l}\text { LMW Dextran } \\
\text { (CosmoFer) }\end{array}$ & $73 \mathrm{kDa}$ & $5-20 \mathrm{~h}$ & $\begin{array}{c}\text { Maximum single } \\
\text { infusion of } 20 \mathrm{mg} / \mathrm{kg} \\
\text { over } 4-6 \mathrm{~h}\end{array}$ & $\begin{array}{l}\text { Immunoglobulin-E mediated } \\
\text { anaphylactoid reaction }\end{array}$ \\
\hline $\begin{array}{l}\text { Sucrose } \\
\text { (Venofer) }\end{array}$ & $34-60 \mathrm{kDa}$ & $5-6 \mathrm{~h}$ & $\begin{array}{l}\text { Single infusion up to } \\
200 \mathrm{mg} \text { over } 30 \mathrm{~min}\end{array}$ & $\begin{array}{l}\text { Multiple sessions needed in } \\
\text { severe anaemia }\end{array}$ \\
\hline $\begin{array}{l}\text { Carboxymaltose } \\
\text { (Ferrinject) }\end{array}$ & $150 \mathrm{kDa}$ & $7-12 \mathrm{~h}$ & \multirow{2}{*}{$\begin{array}{l}\text { Single dose infusion of } \\
1000 \mathrm{mg} \text { over } 15 \mathrm{~min} \\
\text { (max dose of } 20 \mathrm{mg} / \mathrm{kg} \text { ) }\end{array}$} & Hypophosphataemia \\
\hline $\begin{array}{l}\text { Isomaltoside } \\
\text { (Monofer) }\end{array}$ & $1000 \mathrm{kDa}$ & 1-4 days & & Limited data in IBD \\
\hline $\begin{array}{l}\text { Gluconate } \\
\text { (Ferrlecit) }\end{array}$ & $37 \mathrm{kDa}$ & $1 \mathrm{~h}$ & 8 infusions of $125 \mathrm{mg}$ & Not currently for use in IBD \\
\hline Ferumoxytol & $721 \mathrm{kDa}$ & $14-21 \mathrm{~h}$ & $\begin{array}{l}510 \mathrm{mg} \text { can be given in } \\
\text { less than } 1 \text { min }\end{array}$ & $\begin{array}{l}\text { High rate of adverse events } \\
\text { Interference with MRI }\end{array}$ \\
\hline
\end{tabular}

HMW: high molecular weight; LMW: low molecular weight; IBD: inflammatory bowel disease; MRI: magnetic resonance imaging. 


\subsection{Dextran}

The high molecular weight (HMW) iron replacement therapy is also known as DexFerrum [44]. It has a molecular weight of $100-500 \mathrm{kDa}$ and is considered to be a stable parenteral iron product with a plasma half-life of 3-4 days [10]. The increased stability of this compound allows for high dose single administrations [1]. However, this compound has an increased risk for anaphylaxis [47] and due to its unfavourable safety profile, HMW dextran should be avoided [48]. The low molecular weight (LMW) dextran (CosmoFer), $73 \mathrm{kDa}$, can be safely administered with a 2 to 12-fold lower risk of life and non-life-threatening side effects compared to HMW dextran. Compared to the HMW dextran, there is a much smaller risk of an immunoglobulin-E mediated anaphylactoid reaction. However, this risk is still greater than the newer iron salt formulations. Only the LMW dextran is currently available for use in Europe at a maximum single dose of $200 \mathrm{mg}$ administered over a minimum of $30 \mathrm{~min}$. [49]

\subsection{Sucrose (Venofer, Vifor)}

Iron sucrose has a molecular weight of $34-60 \mathrm{kDa}$ and is released quickly into circulation due to its relatively fast half-life of $5-6 \mathrm{~h}[10,50,51]$. It is the most extensively studied IV iron preparation in IBD patients [52]. A slow injection of 100-200 $\mathrm{mg}$ (300 mg in some countries) given 2-3 times a week over $30 \mathrm{~min}$ is advised. It can also be infused slowly at a maximum dose of $500 \mathrm{mg}$ once a week [50]. If the infusion is given too quickly ( $>4 \mathrm{mg} / \mathrm{min}$ ) or a single total iron dose is too high $(>7 \mathrm{mg} / \mathrm{kg})$, the non-transferrin bound iron may cause dyspnoea, tachycardia and transient hypotension [53]. Iron sucrose is safe and well-tolerated even if previously intolerant to other IV iron products and does not carry the risk of dextran-induced anaphylactic reactions. Studies have shown an association between an improvement in QoL and treatment response rate $(65-75 \%)$, which should be noticeable within $4-8$ weeks. Furthermore, this preparation can be used after the first trimester in pregnancy and post-partum [10]. The main disadvantage to iron sucrose is that multiple sessions are needed in severe anaemia to replace the estimated iron deficit [50].

\subsection{Ferric Carboxymaltose (Ferrinject)}

Alongside iron sucrose, this is also extensively studied and used in IBD patients [17]. It is highly stable and has a molecular weight of $150 \mathrm{kDa}$ [24,54]. It can be safely administered at a dose of $1000 \mathrm{mg}$ within $15 \mathrm{~min}$ [23]. Multiple studies have confirmed the superiority of ferric carboxymaltose in IBD patients compared to oral iron, demonstrating the drug to be efficacious and well-tolerated with a faster rise in $\mathrm{Hb}$ [55]. Compared to iron sucrose, it proved to have greater efficacy and compliance with a good safety profile [56]. A potential consequence seen with carboxymaltose is hypophosphataemia. This is usually asymptomatic and evident within $24 \mathrm{~h}$ of administration, reaching a peak in 1 to 2 weeks [57]. Phosphate concentrations generally return to baseline by six weeks. If patients receive multiple or recurrent infusions, hypophosphataemia may last for longer periods and can rarely result in osteomalacia [57].

\subsection{Ferric Gluconate (Ferrlecit, Sanofi)}

This is a labile iron formulation, so iron is released quickly [58]. It has a molecular weight of $37 \mathrm{kDa}$ [24]. This preparation is not typically used in IBD patients with more extensive studies conducted in chronic kidney disease (CKD) patients, demonstrating adequate safety and efficacy in patients on haemodialysis. It is generally given over eight infusions of $125 \mathrm{mg}$ during eight consecutive dialysis sessions [58]. Side effects include nausea, hypotension, tachycardia, dyspnoea and oedema of the lungs, hands and feet. These symptoms should not be mistaken for anaphylaxis [10].

\subsection{Ferumoxytol}

This is a new iron salt formulation with its use not yet approved in Europe [59]. It has a much larger complex $(750 \mathrm{kDa})$ which allows the drug to be given rapidly in large doses [60]. The dose is $510 \mathrm{mg}$ 
administered over less than one minute with a second dose given 3-8 days later [59]. It is currently being used for IDA in CKD with limited data in treatment of anaemia in IBD. Thus far, ferumoxytol has the highest rate for adverse events per million units sold and carries a boxed warning for possible life-threatening allergic reactions [61]. Additionally, ferumoxytol can interfere with MRI examinations due to its paramagnetic nature [62].

\subsection{Ferric Isomaltoside (Monofer)}

This is the latest iron salt formulation and is found to be stable with little labile iron and a very small immunogenic potential [23,63]. The dose is $20 \mathrm{mg} / \mathrm{kg}$, administered within $15 \mathrm{~min}$ [24,64]. Advantages include: full iron repletion being achieved in a single infusion, well-tolerated, safe and effective with no reports of anaphylactic or delayed allergic reactions [23]. Stein et al. demonstrated efficacy with ferric isomaltoside in IBD patients with a rise in $\mathrm{Hb}$ levels and a reduction in faecal calprotectin levels. The study also demonstrated a good safety profile with only $8 \%$ of patients reporting adverse drug reactions, the most common being gastrointestinal upset and skin reactions. However, this was a non-interventional study with a small sample size of only 197 patients [65].

\subsection{Advantages versus Disadvantages of IV Iron}

The primary advantage of IV iron is that it bypasses absorption through the gastrointestinal tract, thereby avoiding further mucosal aggravation and inflammation and producing less side effects. Clinicians also do not have to worry about patient's adherence to medication [47]. Moreover, IV iron can replace iron stores and improve anaemia quicker and more efficiently than oral iron [66], although the clinical significance of this is uncertain [47]. There was a meta-analysis conducted that compared IBD patients who were given IV and oral iron. The results demonstrated that IV iron was more effective at increasing $\mathrm{Hb}$ levels and, due to the reduced adverse events and greater tolerability, there was a lower rate of treatment discontinuation [66]. However, studies have not shown any significant differences in quality of life or disease activity in those with IV versus oral iron [47].

The common disadvantages include a low bioavailability of IV iron and the inconvenience of IV administration. Parenteral iron is more expensive and is an additional cost to the healthcare system, which is a limiting factor in its widespread use [1,47]. However, further studies have shown that the long-term costs of ineffective oral iron therapy are outweighed by the immediate costs of IV iron [67]. Additionally, severe anaphylactoid reactions to HMW dextrans have previously been reported but are now increasingly rare with the newer LMW formulations [1]. In particular, anaphylactic reactions have been reported at 0.24/1000 infusions in IBD [66] with death being reported at 1 for every 5 million doses [68].

The side effect profiles are different for each preparation, however, the most frequently reported in LMW complexes include skin flushing, itching, dyspnoea, wheezing and stridor, myalgia, hypotension, tachycardia, nausea and diarrhoea and periorbital oedema. Serious side effects such as cardiac arrest are rare and are more commonly seen with the older, dextran-containing preparations [24].

\subsection{When to Use IV versus Oral}

This is an ongoing topic of debate between clinicians with no study having provided clear, globally accepted evidence [3]. Some authors promote the use of IV iron only in IBD patients [43], while other authors acknowledge that both routes can be efficacious and safe to use, depending on the dose and formulation used [36,69]. Although oral iron remains the first line treatment for IBD patients in the United States, IV iron is now considered standard treatment for IBD patients in Europe [70]. Regardless, several studies showed that oral iron was still the preferred modality by clinicians [71]. Furthermore, despite the fact that IV iron has been proven to be clinically effective with a well-tolerated safety profile, many clinicians are still reluctant to administer IV iron for concern of its hypersensitivity reactions [50]. Table 3 summarises these findings. 
Table 3. Advantages and disadvantages between oral and intravenous iron.

\begin{tabular}{|c|c|c|}
\hline & Oral Iron & IV Iron \\
\hline Choice of administration & $\begin{array}{l}\text { Mild IDA }(\mathrm{Hb}>100 \mathrm{~g} / \mathrm{L}) \\
\text { Quiescent IBD }\end{array}$ & $\begin{array}{l}\text { Severe anaemia }(\mathrm{Hb}<100 \mathrm{~g} / \mathrm{L}) \\
\text { Intolerant to oral iron } \\
\text { Moderate to severe IBD activity }\end{array}$ \\
\hline Pros & $\begin{array}{l}\text { Greater availability } \\
\text { Ease of administration } \\
\text { Low cost }\end{array}$ & $\begin{array}{l}\text { Bypasses GI tract absorption } \\
\text { Less side effects }\end{array}$ \\
\hline Cons & $\begin{array}{l}\text { Side effects with poor patient tolerance } \\
\text { Discontinuation in } 20 \% \\
\text { Increases IBD activity } \\
\text { Disrupts microbiome }\end{array}$ & $\begin{array}{c}\text { Low bioavailability } \\
\text { Inconvenience of IV application } \\
\text { Greater cost } \\
\text { Risk of hypersensitivity reaction * }\end{array}$ \\
\hline
\end{tabular}

${ }^{*}$ Hypersensitivity risk rare in LMW (low molecular weight) dextran and newer IV formulations. IDA: iron deficiency anaemia; GI: gastrointestinal; Hb: haemoglobin; IBD: inflammatory bowel disease.

\section{Blood Transfusions}

Blood transfusions are generally not recommended in IDA due to the high risk of complications [24]. Studies have shown that the generous use of blood transfusions in upper gastrointestinal bleeds has been associated with an increased mortality risk in patients as well as an increased risk of nosocomial infection rate [72]. If the decision is to proceed with a blood transfusion, it should be done with caution and should not be intended for repeated transfusions. Specifically, blood transfusions should be reserved for patients who are severely anaemic $(\mathrm{Hb}<70 \mathrm{~g} / \mathrm{L})$, haemodynamically unstable or have co-morbid conditions such as coronary heart disease or chronic pulmonary disease [20]. Importantly, transfusions should be used only as a temporary measure to increase $\mathrm{Hb}$ levels and iron replacement is still needed to replenish iron stores [1].

\section{Erythropoietin-Stimulating Agents}

Erythropoietin (Epo) should be considered as second line treatment for IBD patients with severe or symptomatic anaemia refractory to IV iron. In this instance, patients may have underlying ACD which is mistaken for IDA [20]. Currently, large long-term studies on the use of Epo in IBD is lacking with more data for patients with CKD [20,73]. There are several disadvantages to using Epo, including risk of thromboembolic events, stroke, cardiovascular events and death [74]. This is an important factor as IBD already has a high risk of venous thromboembolic events, particularly in high-risk patients with ulcerative colitis and in active disease [23]. The target $\mathrm{Hb}$ should be 130-140 $\mathrm{g} / \mathrm{L}$ and a rapid increase of greater than $100 \mathrm{~g} / \mathrm{L}$ in 2 weeks has been shown to be harmful for patients with CKD. ECCO recommends a target $\mathrm{Hb}$ of less than $120 \mathrm{~g} / \mathrm{L}$ to minimise side effects, which include hypertension, oedema, fever, dizziness and rare red cell aplasia secondary to anti-Epo antibodies. Giving Epo can cause an increased demand for iron in the bone marrow, thus IV iron should also be given, aiming for a target ferritin level greater than $200 \mathrm{ug} / \mathrm{L}$ to prevent functional iron deficiency [20].

\section{Follow Up and Maintenance}

The goal of iron supplementation, whether given IV or orally, should be the complete normalisation of $\mathrm{Hb}$ and iron storage. An adequate response is an increase in $\mathrm{Hb}$ of at least $200 \mathrm{~g} / \mathrm{L}$ or normalisation within 4 weeks of treatment. However, depending on the severity and underlying cause of anaemia, $\mathrm{Hb}$ correction can take up to three months or longer to replenish iron stores. Iron storage can be assessed with ferritin and transferrin saturation. This should be checked 8-12 weeks after the last IV treatment as levels can be falsely elevated [1]. When using oral therapy, ferritin can increase within 1-2 weeks. Treatment response can also be demonstrated more rapidly with reticulocyte count and reticulocyte production index, which is increased within 1-2 weeks of oral or IV iron. When giving IV iron, ferritin levels of $800 \mathrm{ug} / \mathrm{L}$ and transferrin saturations of $50 \%$ should be used as the upper limits 
to prevent iron overload [24]. When deciding to stop iron therapy, iron storage levels should be above the lower limits of normal to prevent risk of recurrence [20].

Unfortunately, iron deficiency and IDA can recur often in IBD patients with ongoing risk factors. Post iron replacement, ferritin levels of $<100 \mathrm{ug} / \mathrm{L}$ are more likely to recur within the first four months, 100-400 ug/L within the next year and $>400 \mathrm{ug} / \mathrm{L}$ after two years [75]. Faster recurrence correlates with disease activity even if patients are asymptomatic and found to have low inflammatory markers [24]. Thus, appropriate IBD management should be undertaken concomitantly with iron replacement to prevent further iron losses [1]. Following correction of iron, IBD patients should be monitored for IDA recurrence every 3 months for at least one year and then 6-12 months thereafter. This includes checking $\mathrm{Hb}$, ferritin, transferrin saturations and CRP. Vitamin B12 and folic acid should be measured on a yearly basis for patients and more frequently in patients with extensive small bowel resection particularly if there is ileal involvement including ileal pouch surgery. Once ferritin falls below 100 or $\mathrm{Hb}$ drops below normal levels, treatment should be restarted using the same route of administration as the initial formulation [20].

\section{Conclusions}

IDA is the most common extraintestinal manifestation of IBD, with debilitating consequences on patients' QoL. Treatment should be initiated as soon as IDA has been identified and, once corrected, levels should be monitored routinely to avoid recurrence. There is no consensus amongst gastroenterologists as to which iron preparation is best. Oral iron formulations are restricted in their use due to poor tolerability and patient compliance issues, although there are promising data for the newer oral iron formulations. Although IV iron formulations have been shown to be better tolerated and lead to a faster $\mathrm{Hb}$ rise than oral iron, there is still hesitancy amongst gastroenterologists to promote this administration due to its hypersensitivity risk. Large comparative trials to determine safety and efficacy between different formulations are now needed to establish clinician unanimity for standard treatment guidelines.

Author Contributions: A.K. has researched the literature, written the manuscript and made critical revisions. M.J.B. has developed the concept and was involved in critical revisions of the manuscript. All authors have read and agreed to the published version of the manuscript.

Funding: M.J.B. has received grants and travel expenses from Vifor International and Tillots Pharma, outside of the submitted work. A.K. reports no competing interests.

Conflicts of Interest: The authors declare no conflict of interest.

\section{References}

1. Jimenez, K.M.; Gasche, C. Management of Iron Deficiency Anaemia in Inflammatory Bowel Disease. Acta Haematol. 2019, 142, 30-36. [CrossRef] [PubMed]

2. Ng, S.C.; Shi, H.Y.; Hamidi, N.; Underwood, F.E.; Tang, W.; Benchimol, E.I.; Sung, J.J. Worldwide incidence and prevalence of inflammatory bowel disease in the 21st century: A systematic review of population-based studies. Lancet 2018, 390, 2769-2778. [CrossRef]

3. D'Amico, F.; Peyrin-Biroulet, L.; Danese, S. Oral Iron for IBD Patients: Lessons Learned at Time of COVID-19 Pandemic. J. Clin. Med. 2020, 9, 1536. [CrossRef] [PubMed]

4. DeSilva, A.D.; Mylonaki, M.; Rampton, D.S. Oral iron therapy in inflammatory bowel disease: Usage, tolerance, and efficacy. Inflamm. Bowel Dis. 2003, 9, 316-320. [CrossRef]

5. Filmann, N.; Rey, J.; Schneeweiss, S.; Ardizzone, S.; Bager, P.; Bergamaschi, G.; Vavricka, S.R. Prevalence in anemia in inflammatory bowel diseases in European countries: A systematic review and individual patient data meta-analysis. Inflamm. Bowel Dis. 2014, 20, 936-945. [CrossRef]

6. Høivik, M.L.; Reinisch, W.; Cvancarova, M.; Moum, B.; The IBSEN Study Group. Anaemia in inflammatory bowel disease: A population-based 10-year follow-up. Aliment. Pharmacol. Ther. 2013, 39, 69-76. [CrossRef] 
7. Vegh, Z.; Kürti, Z.; Gonczi, L.; Golovics, P.A.; Lovasz, B.D.; Szita, I.; Balogh, M.; Pandur, T.; Vavricka, S.R.; Rogler, G.; et al. Association of extraintestinal manifestations and anaemia with disease outcomes in patients with inflammatory bowel disease. Scand. J. Gastroenterol. 2016, 51, 848-854. [CrossRef]

8. Rogler, G.; Evavricka, S. Anemia in Inflammatory Bowel Disease: An Under-Estimated Problem? Front. Med. 2015, 1, 58. [CrossRef]

9. Evstatiev, R.; Gasche, C. Iron sensing and signalling. Gut 2011, 61, 933-952. [CrossRef]

10. Gasche, C.; Lomer, M.C.E.; Cavill, I.; Weiss, G. Iron, anaemia, and inflammatory bowel diseases. Gut 2004, 53, 1190-1197. [CrossRef]

11. Young, I.; Parker, H.M.; Rangan, A.M.; Prvan, T.; Cook, R.L.; Donges, C.E.; Steinbeck, K.; O’Dwyer, N.; Cheng, H.L.; Franklin, J.; et al. Association between Haem and Non-Haem Iron Intake and Serum Ferritin in Healthy Young Women. Nutrients 2018, 10, 81. [CrossRef] [PubMed]

12. Gulec, S.; Anderson, G.J.; Collins, J.F. Mechanistic and regulatory aspects of intestinal iron absorption. Am. J. Physiol. Liver Physiol. 2014, 307, G397-G409. [CrossRef] [PubMed]

13. Adrian, R.W.; Oates, P.S. Mechanisms of heme iron absorption: Current questions and controversies. World J. Gastroenterol. 2008, 14, 4101-4110. [CrossRef]

14. Bhandari, S.; Pereira, D.I.A.; Chappell, H.F.; Drakesmith, A. Intravenous Irons: From Basic Science to Clinical Practice. Pharmaceuticals 2018, 11, 82. [CrossRef] [PubMed]

15. Ganz, T.; Nemeth, E. Hepcidin and iron homeostasis. Biochim. Biophys. Acta Bioenerg. 2012, 1823, $1434-1443$. [CrossRef] [PubMed]

16. Kaitha, S.; Bashir, M.; Ali, T. Iron deficiency anemia in inflammatory bowel disease. World J. Gastrointest. Pathophysiol. 2015, 6, 62-72. [CrossRef]

17. Niepel, D.; Klag, T.; Malek, N.P.; Wehkamp, J. Practical guidance for the management of iron deficiency in patients with inflammatory bowel disease. Ther. Adv. Gastroenterol. 2018, 11, 1-16. [CrossRef]

18. Nielsen, O.H.; Soendergaard, C.; Vikner, M.E.; Weiss, G. Rational Management of Iron-Deficiency Anaemia in Inflammatory Bowel Disease. Nutrients 2018, 10, 82. [CrossRef]

19. World Health Organisation. Centers for Disease Control and Prevention. Assessing the Iron Status or Populations, 2nd ed.; World Health Organisation: Geneva, Switzerland, 2007.

20. Dignass, A.; Gasche, C.; Bettenworth, D.; Birgegård, G.; Danese, S.; Gisbert, J.P.; Gomollón, F.; Iqbal, T.; Katsanos, K.; Koutroubakis, I.; et al. European Consensus on the Diagnosis and Management of Iron Deficiency and Anaemia in Inflammatory Bowel Diseases. J. Crohns Colitis 2015, 9, 211-222. [CrossRef]

21. Reinisch, W.; Staun, M.; Bhandari, S.; Muñoz, M. State of the iron: How to diagnose and efficiently treat iron deficiency anemia in inflammatory bowel disease. J. Crohns Colitis 2013, 7, 429-440. [CrossRef]

22. Oustamanolakis, P.; Koutroubakis, I.E.; Messaritakis, I.; Kefalogiannis, G.; Niniraki, M.; Kouroumalis, E.A. Measurement of reticulocyte and red blood cell indices in the evaluation of anemia in inflammatory bowel disease. J. Crohns Colitis 2011, 5, 295-300. [CrossRef] [PubMed]

23. Stein, J.; Dignass, A.U. Management of iron deficiency anemia in inflammatory bowel disease-A practical approach. Ann. Gastroenterol. 2013, 26, 104-113. [PubMed]

24. Nielsen, O.H.; Ainsworth, M.; Coskun, M.; Weiss, G. Management of Iron-Deficiency Anemia in Inflammatory Bowel Disease. Medicine 2015, 94, e963. [CrossRef] [PubMed]

25. Gisbert, J.P.; Gomollón, F. Common Misconceptions in the Diagnosis and Management of Anemia in Inflammatory Bowel Disease. Am. J. Gastroenterol. 2008, 103, 1299-1307. [CrossRef] [PubMed]

26. Lopez, A.; Cacoub, P.; Macdougall, I.C.; Peyrin-Biroulet, L. Iron deficiency anaemia. Lancet 2016, 387, $907-916$. [CrossRef]

27. Stein, J.; Hartmann, F.; Dignass, A. Diagnosis and management of iron deficiency anemia in patients with IBD. Nat. Rev. Gastroenterol. Hepatol. 2010, 7, 599-610. [CrossRef]

28. World Health Organization. Nutritional Anaemias: Tools for Effective Prevention and Control; World Health Organisation: Geneva, Switzerland, 2017.

29. Gisbert, J.P.; Bermejo, F.; Pajares, R.; Pérez-Calle, J.-L.; Rodríguez, M.; Algaba, A.; Mancenido, N.; De La Morena, C.S.F.; Carneros, J.A.; McNicholl, A.G.; et al. Oral and intravenous iron treatment in inflammatory bowel disease: Hematological response and quality of life improvement. Inflamm. Bowel Dis. 2009, 15, 1485-1491. [CrossRef]

30. Kulnigg, S.; Gasche, C. Systematic review: Managing anaemia in Crohn's disease. Aliment. Pharmacol. Ther. 2006, 24, 1507-1523. [CrossRef] 
31. Gómez-Ramírez, S.; Brilli, E.; Tarantino, G.; Muñoz, M. Sucrosomial ${ }^{\circledR}$ Iron: A New Generation Iron for Improving Oral Supplementation. Pharmaceuticals 2018, 11, 97. [CrossRef]

32. Fuqua, B.K.; Vulpe, C.D.; Anderson, G.J. Intestinal iron absorption. J. Trace Elem. Med. Biol. 2012, 26, 115-119. [CrossRef]

33. Stoffel, N.U.; Cercamondi, C.I.; Brittenham, G.; Zeder, C.; Geurts-Moespot, A.J.; Swinkels, D.W.; Zimmermann, M.B. Iron absorption from oral iron supplements given on consecutive versus alternate daus and as single morning doses versus twice-daily split dosing in iron-depleted women: Two open-label, randomised controlled trials. Lancet Haematol. 2017, 4, e524-e533. [CrossRef]

34. Moretti, D.; Goede, J.S.; Zeder, C.; Jiskra, M.; Chatzinakou, V.; Tjalsma, H.; Melse-Boonstra, A.; Brittenham, G.; Swinkels, D.W.; Zimmermann, M.B. Oral iron supplements increase hepcidin and decrease iron absorption from daily or twice-daily doses in iron-depleted young women. Blood 2015, 126, 1981-1989. [CrossRef] [PubMed]

35. Khoury, A.P.; Pagan, K.A.; Farland, M.Z. Ferric Maltol: A New Oral Iron Formulation for the Treatment of Iron Deficiency in Adults. Ann. Pharmacother. 2020. [CrossRef] [PubMed]

36. Asche, C.; Ahmad, T.; Tulassay, Z.; Baumgart, D.C.; Bokemeyer, B.; Büning, C.; Howaldt, S.; Stallmach, A. Ferric maltol is effective in correcting iron deficiency anemia in patients with inflammatory bowel disease: Results from a phase 3 clinical trial program. Inflamm. Bowel Dis. 2015, 21, 579-588. [CrossRef]

37. Howaldt, S.; Jacob, I.; Sampson, M.; Akriche, F. P567 Impact of oral ferric maltol and IV iron on health-related quality of life in patients with iron deficiency anaemia and inflammatory bowel disease, and relationship with haemoglobin and serum iron. J. Crohns Colitis 2020, 14, S478-S479. [CrossRef]

38. Accrufer. Package Insert; Shield Therapeutics 2019, UK. Available online: https://www.accessdata.fda.gov/ drugsatfda_docs/label/2019/212320Orig1s000lbl.pdf (accessed on 15 October 2020).

39. Riccio, E.; Sabbatini, M.; Capuano, I.; Pellegrino, A.M.; Petruzzelli, L.A.; Pisani, A. Oral Sucrosomial ${ }^{\circledR}$ iron versus intravenous iron for recovering iron deficiency anaemia in ND-CKD patients: A cost-minimization analysis. BMC Nephrol. 2020, 21, 1-8. [CrossRef]

40. Abbati, G.; Incerti, F.; Boarini, C.; Pileri, F.; Bocchi, D.; Ventura, P.; Buzzetti, E.; Pietrangelo, A. Safety and efficacy of sucrosomial iron in inflammatory bowel disease patients with iron deficiency anemia. Intern. Emerg. Med. 2018, 14, 423-431. [CrossRef]

41. Howaldt, S.; Jacob, I.; Sampson, M.; Akriche, F. P331 Productivity loss in patients with inflammatory bowel disease receiving treatment for iron deficiency anaemia: A comparison of ferric maltol and IV iron. J. Crohns Coliti 2020, 14, S319-S320. [CrossRef]

42. Cook, J.D. Diagnosis and management of iron-deficiency anaemia. Best Pr. Res. Clin. Haematol. 2005, 18, 319-332. [CrossRef]

43. Gasche, C.; Berstad, A.; Befrits, R.; Beglinger, C.; Dignass, A.; Erichsen, K.; Gomollón, F.; Hjortswang, H.; Koutroubakis, I.; Kulnigg, S.; et al. Guidelines on the diagnosis and management of iron deficiency and anemia in inflammatory bowel diseases. Inflamm. Bowel Dis. 2007, 13, 1545-1553. [CrossRef]

44. Lee, T.; Clavel, T.; Smirnov, K.; Schmidt, A.; Lagkouvardos, I.; Walker, A.; Lucio, M.; Michalke, B.; Schmitt-Kopplin, P.; Fedorak, R.; et al. Oral versus intravenous iron replacement therapy distinctly alters the gut microbiota and metabolome in patients with IBD. Gut 2016, 66, 863-871. [CrossRef] [PubMed]

45. Koch, T.A.; Myers, J.; Goodnough, L.T. Intravenous Iron Therapy in Patients with Iron Deficiency Anemia: Dosing Considerations. Anemia 2015, 2015, 763576. [CrossRef] [PubMed]

46. Stein, J.; Connor, S.; Virgin, G.; Ong, D.E.H.; Pereyra, L. Anemia and iron deficiency in gastrointestinal and liver conditions. World J. Gastroenterol. 2016, 22, 7908-7925. [CrossRef] [PubMed]

47. Lee, T.W.; Kolber, M.R.; Fedorak, R.N.; Van Zanten, S.V. Iron replacement therapy in inflammatory bowel disease patients with iron deficiency anemia: A systematic review and meta-analysis. J. Crohns Colitis 2012, 6, 267-275. [CrossRef] [PubMed]

48. Auerbach, M.; Ballard, H. Clinical Use of Intravenous Iron: Administration, Efficacy, and Safety. Hematology 2010, 2010, 338-347. [CrossRef]

49. Chertow, G.M.; Mason, P.D.; Vaage-Nilsen, O.; Ahlmén, J. Update on adverse drug events associated with parenteral iron. Nephrol. Dial. Transplant. 2005, 21, 378-382. [CrossRef]

50. Muñoz, M.; Gómez-Ramírez, S.; García-Erce, J.A.; Muñoz, S.G.M.; Ramí, M.; Rez, J.; Garciacute, A.; Erce, A. Intravenous iron in inflammatory bowel disease. World J. Gastroenterol. 2009, 15, 4666-4674. [CrossRef] 
51. Venofer (Iron Sucrose). Electronic Medicines Compendium. Available online: https://www.medicines.org. uk/emc/product/5911/smpc\#gref (accessed on 15 October 2020).

52. Schröder, O.; Mickisch, O.; Seidler, U.; De Weerth, A.; Dignass, A.U.; Herfarth, H.; Reinshagen, M.; Schreiber, S.; Junge, U.; Schrott, M.; et al. Intravenous iron sucrose is superior to oral iron supplementation for the treatment of iron deficiency anemia in patients with inflammatory bowel disease-A randomised, controlled, open-label, multicentre study. Am. J. Gastroenterol. 2005, 100, 2503-2509. [CrossRef]

53. Kooistra, M.P.; Kersting, S.; Gosriwatana, I.; Lu, S.; Nijhoff-Schutte, J.; Hider, R.C.; Marx, J.J. Non-transferrin bound iron in the plasma of haemodialysis patients after intravenous iron saccharate infusion. Eur. J. Clin. Investig. 2002, 32, 36-41. [CrossRef]

54. Ferrinject (Ferric Carboxymaltose). Electronic Medicines Compendium. Available online: https://www. medicines.org.uk/emc/product/5910/smpc\#gref (accessed on 15 October 2020).

55. Kulnigg, S.; Stoinov, S.; Simanenkov, V.; Dudar, L.V.; Karnafel, W.; Garcia, L.C.; Sambuelli, A.M.; D’Haens, G.; Gasche, C. A Novel Intravenous Iron Formulation for Treatment of Anemia in Inflammatory Bowel Disease: The Ferric Carboxymaltose (FERINJECT ${ }^{\circledR}$ ) Randomized Controlled Trial. Am. J. Gastroenterol. 2008, 103, 1182-1192. [CrossRef]

56. Evstatiev, R.; Marteau, P.; Iqbal, T.; Khalif, I.L.; Stein, J.; Bokemeyer, B.; Chopey, I.V.; Gutzwiller, F.S.; Riopel, L.; Gasche, C. FERGIcor, a Randomized Controlled Trial on Ferric Carboxymaltose for Iron Deficiency Anemia in Inflammatory Bowel Disease. Gastroenterology 2011, 141, 846-853.e2. [CrossRef] [PubMed]

57. Wolf, M.; Koch, T.A.; Bregman, D.B. Effects of iron deficiency anemia and its treatment on fibroblast growth factor 23 and phosphate homeostasis in women. J. Bone Miner. Res. 2013, 28, 1793-1803. [CrossRef] [PubMed]

58. Silverstein, S.B.; Rodgers, G.M. Parenteral iron therapy options. Am. J. Hematol. 2004, 76, 74-78. [CrossRef] [PubMed]

59. McCormack, P.L. Ferumoxytol: In iron deficiency anaemia in adults with chronic kidney disease. Drugs 2012, 72, 2013-2022. [CrossRef]

60. Provenzano, R.; Schiller, B.; Rao, M.; Coyne, D.; Brenner, L.; Pereira, B.J. Ferumoxytol as an intravenous iron replacement therapy in hemodialysis patients. Clin. J. Am. Soc. Nephrol. 2009, 4, 386-393. [CrossRef]

61. Bailie, G.R. Compariuson of rates of reported adverse events associated with i.v. iron products in the United States. Am. J. Health Syst. Pharm. 2012, 69, 310-320. [CrossRef]

62. Schieda, N. Parenteral ferumoxytol interaction with magnetic resonance imaging: A case report, review of the literature and advisory warning. Insights Imaging 2013, 4, 509-512. [CrossRef]

63. Kalra, P.A.; Bhandari, S. Efficacy and safety of iron isomaltoside (Monofer ${ }^{\circledR}$ ) in the management of patients with iron deficiency anemia. Int. J. Nephrol. Renov. Dis. 2016, 9, 53-64. [CrossRef]

64. Monofer. Electronic Medicines Compendium. Available online: https://www.medicines.org.uk/EMC/ medicine/23669/SPC/Monofer+100\%C2\%A0mg+ml+solution+for+injection+infusion/\#gref (accessed on 15 October 2020).

65. Stein, J.; Walper, A.; Klemm, W.; Farrag, K.; Aksan, A.C.; Dignass, A. Safety and efficacy of intravenous iron isomaltoside for correction of anaemia in patients with inflammatory bowel disease in everyday clinical practice. Scand. J. Gastroenterol. 2018, 53, 1059-1065. [CrossRef]

66. Bonovas, S.; Fiorino, G.; Allocca, M.; Lytras, T.; Tsantes, A.; Peyrin-Biroulet, L.; Danese, S. Intravenous versus oral iron for the treatment of anemia in inflammatory bowel disease: A systematic review and meta-analysis of randomised controlled trials. Medicine 2006, 95, e2308. [CrossRef]

67. Stein, J.; Haas, J.S.; Ong, S.H.; Borchert, K.; Hardt, T.; Lechat, E.; Nip, K.; Foerster, D.; Braun, S.; Baumgart, D.C. Oral versus intravenous iron therapy in patients with inflammatory bowel disease and iron deficiency with and without anemia in Germany-A real-world evidence analysis. Clin. Outcomes Res. 2018, 10, 93-103. [CrossRef] [PubMed]

68. Rampton, D.S.; Folkersen, J.; Fishbane, S.; Hedenus, M.; Howaldt, S.; Locatelli, F.; Patni, S.; Szebeni, J.; Weiss, G. Hypersensitivity reactions to intravenous iron: Guidance for risk minimization and management. Haematologica 2014, 99, 1671-1676. [CrossRef] [PubMed]

69. Rizvi, S.; Schoen, R.E. Supplementation With Oral vs. Intravenous Iron for Anemia With IBD or Gastrointestinal Bleeding: Is Oral Iron Getting a Bad Rap? Am. J. Gastroenterol. 2011, 106, 1872-1879. [CrossRef] [PubMed]

70. Jimenez, K.; Gasche, C.; Auerbach, M. On both sides of the ocean. Blood Transfus. 2016, 14, 197. [PubMed] 
71. Abhyankar, A.; Moss, A.C. Iron Replacement in Patients with Inflammatory Bowel Disease: A Systematic Review and Meta-analysis. Inflamm. Bowel Dis. 2015, 21, 1976-1981. [CrossRef] [PubMed]

72. Jairath, V.; Kahan, B.C.; Gray, A.; Doré, C.J.; Mora, A.; Dyer, C.; Stokes, E.A.; Llewelyn, C.; Bailey, A.; Dallal, H.; et al. Restrictive vs. Liberal Blood Transfusion for Acute Upper Gastrointestinal Bleeding: Rationale and Protocol for a Cluster Randomized Feasibility Trial. Transfus. Med. Rev. 2013, 27, 146-153. [CrossRef]

73. Tsiolakidou, G.; Koutroubakis, I.E. Stimulating erythropoiesis in inflammatory bowel disease associated anemia. World J. Gastroenterol. 2007, 13, 4798-4806. [CrossRef]

74. Unger, E.F.; Thompson, A.M.; Blank, M.J.; Temple, R. Erythropoiesis-Stimulating Agents-Time for a Reevaluation. N. Engl. J. Med. 2010, 362, 189-192. [CrossRef]

75. Kulnigg, S.; Teischinger, L.; Dejaco, C.; Waldhoer, T.; Gasche, C. W1124 Rapid Recurrence of IBD-Associated Anemia and Iron Deficiency After Intravenous Iron Sucrose and Erythropoietin Treatment. Gastroenterology 2009, 136, 1460-1467. [CrossRef]

Publisher's Note: MDPI stays neutral with regard to jurisdictional claims in published maps and institutional affiliations.

(C) 2020 by the authors. Licensee MDPI, Basel, Switzerland. This article is an open access article distributed under the terms and conditions of the Creative Commons Attribution (CC BY) license (http://creativecommons.org/licenses/by/4.0/). 